\title{
SAMPAH ANORGANIK MENJADI KERAJINAN TAS PADA KELOMPOK PROGRAM KELUARGA HARAPAN (PKH) DI KECAMATAN DELI TUA
}

\author{
Adek Cerah Kurnia Azis \\ Jurusan Seni Rupa, Fakultas Bahasa dan Seni, Universitas Negeri Medan, Medan, Indonesia \\ *Penulis Korespondensi: adek_peros@yahoo.com
}

\begin{abstract}
Abstrak
Permasalahan mendasar dari kedua Program Keluarga Harapan (PKH) yang menjadi mitra pada Program Pengabdian kepada Masyarakat ini adalah relatif rendahnya pengetahuan serta pengalaman untuk berwirausaha terutama mengutamakan potensi di bidang kerajinan. Mengingat di lokasi setempat banyak sampah-sampah anorganik yang belum dioptimalkan kegunaannya. Sampah ini justru dibakar dan dibiarkan begitu saja, padahal "pembakaran plastik tidak sempurna dan akan menghasilkan gas yang akan terurai diudara menjadi dioksin yaitu bahan beracun”. Sementara banyak produk-produk yang bisa dihasilkan dari sampah tersebut seperti kerajinan, yaitu berupa aneka macam ragam tas. Oleh karena itu tim pelaksana melakukan kegiatan Pengabdian kepada Masyarakat melalui pelatihan dan pendampingan kepada para anggota yang terlibat atau yang bergabung di kedua PKH. Dimana kegiatan ini untuk memanfaakan sampah anorganik (kantong plastik, botol minuman, makanan, dan produk kecantikan, plastik sachet makanan, minuman, dan produk kecantikan) menjadi karya kerajinan tas yang bernilai guna dan jual.
\end{abstract}

Kata kunci: PKH, sampah anorganik, kerajinan tas

\begin{abstract}
The fundamental problem of the two Hope Family Programs (PKH) that become partners in this Community Service Program is the relatively low level of knowledge and experience for entrepreneurship, especially prioritizing the potential in the craft field. Considering that in the local location there are many inorganic wastes that have not been optimized for use. This waste is actually burned and left unchecked, even though "plastic combustion is not perfect and will produce gas that will break down into the air into dioxins which are toxic substances". While many products that can be produced from such waste are like crafts, which are various kinds of bags. Therefore the implementing team carried out Community Service activities through training and mentoring to the members involved or who joined the second PKH. Where this activity is used for inorganic waste (plastic bags, bottled drinks, food, and beauty products, plastic sachets of food, drinks, and beauty products) is a worthwhile and selling bag craft.
\end{abstract}

Keywords: PKH, inorganic waste, bag crafts

\section{PENDAHULUAN}

Program Keluarga Harapan (PKH) Andaliman dan Kenanga merupakan kelompok usaha yang selama ini telah menfasilitasi pemberdayaan ekonomi masyarakat pedesaan. Secara khusus kedua PKH yang berlokasi di Kelurahan Deli Tua Barat, Kecamatan Deli Tua, Kabupaten Deli Serdang ini, berfokus pada pemberdayaan Ibu-ibu rumah tangga yang tujuannya untuk mengasah kreatifitas dibidang kerajinan. Mayoritas dari Ibu-ibu rumah tangga ini berprofesi sebagai penyangga ekonomi keluarga secara informal seperti produsen kue/penganan kecil (kering dan basah), buruh cuci, pengepul barang bekas/daur ulang, penjahit, pembordir dompet/tas, dan produsen perlengkapan rumah tangga dari bahan daur ulang. Permasalahan mendasar dari kedua $\mathrm{PKH}$ yang menjadi mitra pada Program Pengabdian kepada Masyarakat ini adalah relatif rendahnya pengetahuan serta pengalaman mereka untuk berwirausaha terutama mengutamakan potensi mereka dibidang kerajinan. Mengingat di lokasi setempat banyak sampah-sampah anorganik yang belum dioptimalkan kegunaannya. Sampah ini justru dibakar dan dibiarkan begitu saja, padahal "pembakaran plastik tidak sempurna dan akan menghasilkan gas yang akan terurai diudara menjadi dioksin yaitu bahan beracun" (Wikipedia, 2017). Sementara banyak produk-produk yang bisa dihasilkan dari sampah tersebut seperti karya kerajina bisa berupa: aneka macam ragam tas dan bunga hias. Oleh karena itu tim pengusul mengajukan kegiatan Program Pengabdian kepada 
Masyarakat melalui pelatihan dan pendampingan kepada para anggota yang terlibat atau yang bergabung di kedua PKH yang tersebut di atas dalam pemanfaatan sampah anorganik (kantong plastik, botol minuman, makanan, dan produk kecantikan, plastik sachet makanan, minuman, dan produk kecantikan) menjadi karya kerajinan yang bernilai tambah tidak hanya digunakan sehari-hari namun bisa untuk dijual kepada masyarakat.

PKH Andaliman dan Kenanga berdiri sejak tahun 2015 telah berjalan selamah kurang lebih empat tahun dan relatif belum mampu berjalan secara independen tanpa instruktur dan pendampingan dari pihak Kecamatan. Secara teknik pendamping yang juga merupakan staf dari kecamatan (Ibu Nurul) melakukan aktivitas pendampingan yang diadakan pada minggu ke-2 setiap bulannya dengan melakukan aktivitas sederhana, seperti membuat kerajinan dari bahanbahan yang dibeli di pasaran kemudian dibentuk menjadi karya seni seperti membentuk sedotan menjadi bunga. Saat ini PKH Andaliman memiliki 20 orang anggota sementara untuk PKH Kenanga lebih banyak dari Andaliman yaitu 28 orang anggota. $\mathrm{PKH}$ Andaliman dan Kenanga di ketuai oleh ibu Sriwati dan Juliana.

Berdasarkan hasil wawancara dengan ibu Sriwati dan Juliana diperoleh informasi tambahan terkait dengan aktifitas harian khususnya dengan pemanfatan sampah anorganik diantaranya:

1) Selama ini belum ada sosialisasi dan edukasi dari pihak manapun yang memberikan pelatihan kepada kedua kelompok PKH ini untuk pemanfaatan sampah anorganaik menjadi karya kerajinan,

2) Bahan yang masih berorientasi pada pasar (bahan dibeli secara instan di pasaran),

3) Sampah-sampah anorganik masih berserakan di lingkungan mitra, dan

4) Kegitan perkumpulan kelompok $\mathrm{PKH}$ masih belum optimal relatif lebih kepada kegiatan bercerita satu sama lain saja.

PKH Andaliman dan Kenanga di Kelurahan Deli Tua Barat, Kecamatan Deli Tua, memiliki permasalahan mendasar pada relatif masih rendahnya pemahaman dan pengetahuan tentang perkembangan karya kerajinan untuk pengoptimalisasian pemanfaatan sampah anorganik yang berdampak pada independensi pengelolaan dan keberadaan PKH Andaliman dan Kenanga belum sesuai dengan harapan. Namun, demikian berdasarkan hasul survei pengamatan dilapangan, tim pengusul menilai keberadaan kelompok PKH masih dapat dioptimalkan lagi menjadi kegiatan yang bernilai tambah, tidak hanya mampu untuk mencukupi kebutuhan sehari-hari, namun dapat dipasarkan secara komersial. Secara khusus permasalahan umum tersebut dapat dijabarkan dalam beberapa issue spesifik sebagai berikut:

\subsection{Permasalahan kunci}

1) Rendahnya pengetahuan anggota kelompok $\mathrm{PKH}$ Andaliman dan Kenanga dalam pemanfaatan sampah anorganik.

2) Produksi karya kerajinan berbiaya tinggi

3) Kedua anggota kelompk PKH relatif belum memilki aktifitas yang produktif .

\subsection{Issu Spesifik}

1) Latar belakang pendidikan anggota krlompok $\mathrm{PKH}$ yang mayoritas SLTA,

2) Belum pernah terlibat dalam kegiatan pelatihan dari pihak manapun, dan

3) Tidak mengikuti perkembangan karya kerajinan baik dari televisi, media cetak, maupun internet

4) Membeli bahan dari toko,

5) Produk yang dihasilkan tidak diminati pasar,

6) Pola produksi tidak konsisten, dan

7) Kretaifitas dan inovasi dalam desain produk cenderung rendah.

8) Pertemuan rutin anggota tidak berlangsug secara efektif (cenderung hanya untuk bercerita atau seremonial)

9) Tidak ada aktivitas yang bernilai tambah selama pertemuan berlangsung

\subsection{Solusi}

1) Pendampingan berupa pengenalan tentang pemanfaatan sampah anorganik menjadi karya kerajinan,

2) Pengenalan desian, teknik, alat, dan bahan untuk menghasilkan karya kerajinan.

3) Pendampingan yang mengedukasi anggota kelompok kedua PKH untuk memanfaatkan sampah anorganik dari masing-masing rumah dan lingkungan anggota kelompok $\mathrm{PKH}$ yang dapat menghasilkan karya kerajinan,

4) Demontrasi sosialisasi materi pembuatan karya kerajinan berbasis multimedia,

5) Simulasi dan quality control dari tim pengusul.

6) Pendampingan atau edukasi mengenai tata kelolah kelompok PKH dalam bentuk program kerja, pertemuan, aktivitas inti dalam setiap pertemuan.

\subsection{Target dan Luaran}

Target luaran Kegiatan Pengabdian kepada Masyarakat pada Kelompok PKH (Program Keluarga Harapan) di Kecamatan Deli Tua ini diharapkan dapat meningkatkan pemahaman dan pengetahuan para anggota kelompok PKH mitra untuk meningkatkan kualitas dan kuantitas dalam membuat karya kerajinan, selain itu, kegiatan ini juga diharapkan dapat mendorong percepatan independensi pengelolaan Kelompok PKH Andaliman dan Kenanga sehingga dapat meningkatkan daya saing dengan memperbaiki kualitas dan kuantitas karya kerajinan.

Luaran pada kegitan pengabdian kepada masyarakat ini berupa:

1) Banner dalam membuat karya kerajinan menggunaka bahan anorganik (gambar, tutorial, panduan membuat karya kerajinan).

2) Handbook tutorial membuat karya kerajinan 
3) Karya kerajinan

4) Penyusunan progran tahunan disemester dua di tahun 2018

\section{METODE PELAKSANAAN}

Alur pelaksanaan kegiatan pengabdian ini dapat ditinjau pada bagan berikut:

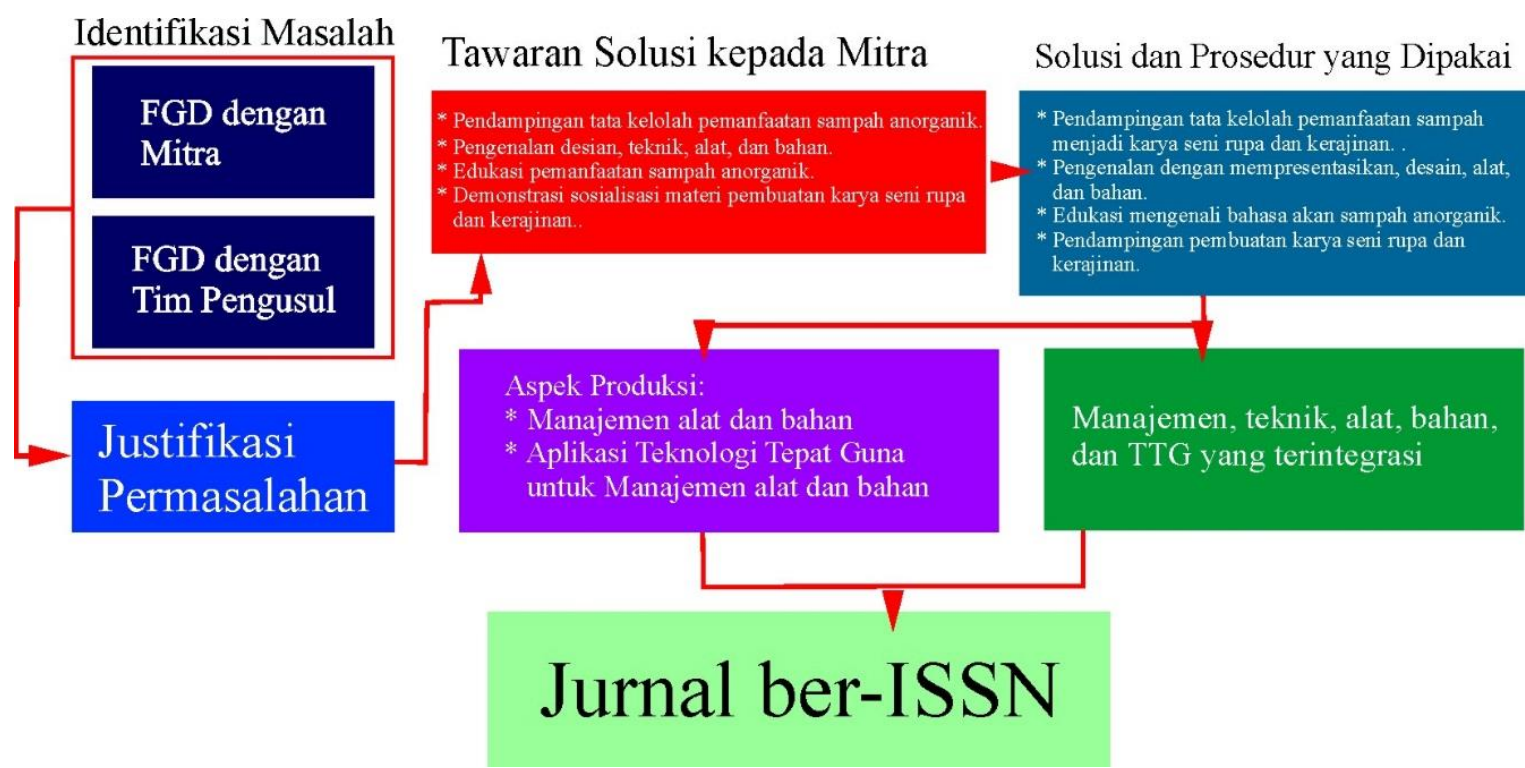

Pengembangan model Kegiatan Pengabdian Kepada Masyarakat untuk meningkatkan kualitas dan kuantitas usaha melalui pembinaan manajemen alat dan bahan dalam membuat karya kerajinan, pengetahuan tentang seni rupa dan kerajinan pada kelompok PKH Andaliman dan Kenanga di Kelurahan Deli Tua Barat, Kecamatan Deli Tua, Kabupaten Deli Serdang ini akan dimulai dengan orientasi ke lapangan, selanjutnya mengidentifikasi permasalahan, studi literatur, dan kegiatan.

Orientasi lapangan dan identifikasi masalah merupakan cara untuk lebih mengetahui masalah yang dihadapi oleh kelompok PKH Andaliman dan Kenanga di Kelurahan Deli Tua Barat Kecamatan Deli Tua Kabupaten Deli Serdang, sehingga dari situlah bisa dicarikan solusi pemecahan masalah yang ada tersebut, kegiatan selanjutnya yaitu mencari solusi terhadap permasalahan yang dirasakan oleh PKH Mitra dalam membuat karya kerajinan melalui studi literatur. Terakhir adalah pelaksanaan instruktur dan pendampingan bagi peningkatan kualitas dan kuantitas kelompok PKH Andaliman dan Kenanga dalam membuat karya kerajinan.

Pelaksanaan Kegiatan Pengabdian kepada Masyarakat LPM Unimed ini pada kelompok PKH Andaliman dan Kenanga dikemas dengan perpaduan pendekatan pelatihan, konsultasi, instruktur, pendampingan, dan workshop. Kegiatan dilakukan menggunakan metode ceramah, diskusi, dan pelatihan oleh tim pengusul yang dibantu dengan 2 (dua) orang tenaga lapangan dari kalangan mahasiswa aktif di Fakultas Bahasa dan Seni (FBS).

\section{HASIL DAN LUARAN YANG DICAPAI}

Sebagaimana yang telah dipaparkan pada bagian Analisis Situasi dan Kondiri Mitra di atas, kegiatan pengabdian Pemanfaatan Sampah Anorganik sebagai Optimalisasi Daya Kreativitas Menuju Wirausaha Madani pada Kelompok Program Keluarga Harapan $(\mathrm{PKH})$ di Kecamatan Deli Tua ini, diutamakan untuk pengoptimalisasian kreativitas dalam membuat karya kerajinan untuk mencapai sebuah wirausaha yang madani. Secara khusus kegiatan pengabdian masyarakat ini dilaksanakan dengan memberikan pelatihan, pendampingan, dan pembinaan terkait dengan kreativitas dalam pemanfaatan sampah anorganik menjadi sebuah karya kerajinan yang bernilai jual. 


\subsection{Pengetahuan Tentang Bahaya Sampah Anorganik}

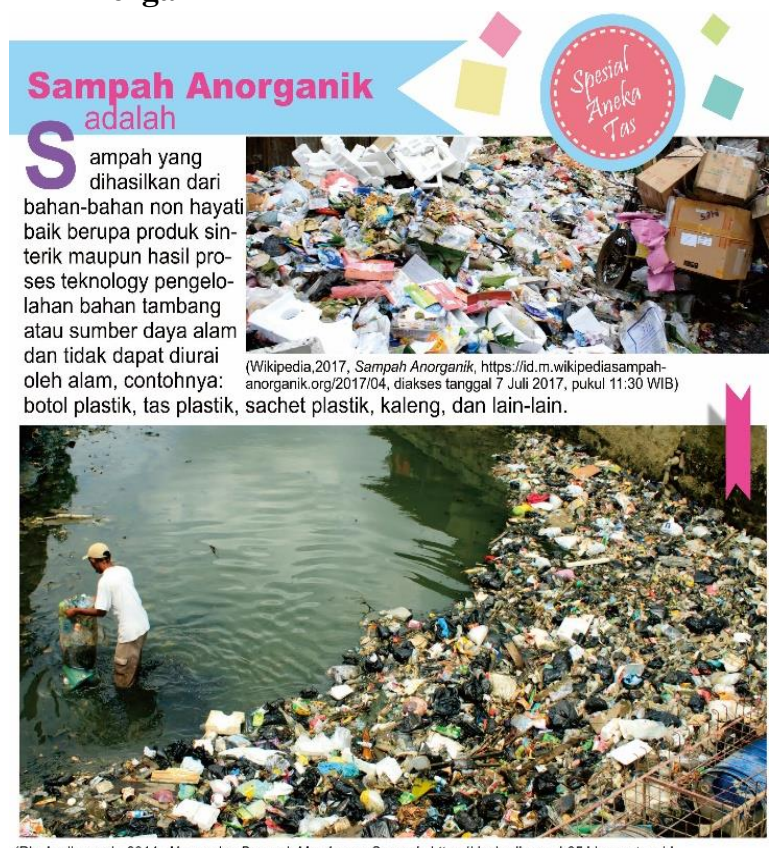

(Rizalardiansyah, 2014, Alasan dan Dampak Membuang Sampah, https:/lizizalardiansyah25.blogspot.co.id
(2014/02/alasan-dan-dampak-membuang-sampah-di.html, diakses tanggal 7 Juli 2017, pukul 11:35 WIB) Bahaya Sampah Anorganik Bagi Lingkungan

P

Pembakaran sampah anorganik seperti plastik yang tidak sempurna dan gas yang dihasilkan akan terurai di udara menjadi dioksin. Senyawa ini tentu sangat berbahaya jika terhirup oleh manusia. Dampaknya, penyakit kronis seperti kanker, pernafasan, gangguang sistem saraf, pembengkakan hati, depresi, dan hepatitis akan mudah menjangkiti siapa pun yang menghirup senyawa ini. (Wikipedia,2017, Sampah Anorganik, https:///id.
diakses tanggal 7 Juli 2017, pukul 11:30 WIB)

\section{$>>\square>>$}

antas, dampak apa yang akan ditimbulkan jika sampah plastik dibuang di perairan? Pertanyaan yang satu in pastinya sangat mudah dijawab karena setiap tahun kita

perairan. Banjir kini bukan lagi menjadi hal yang asing di telinga kita terutama bagi warga yang tinggal di kota besar sampah-sampah plastik yang dibuang di perairan akan menyumbat saluran-saluran air dan tanggul besar sibuang

Mengubur sampah plastik di tanah bukanlah suatu solusi yang tepat untuk menanggulangi permasalahan sampah. Sampah-sampah plastik yang dikubur tidak akan mudah hancur dan membutuhkan waktu hingga puluhan tahun untuk benar-benar hancur. Belum lagi kandungan zat kimia yang terdapat pada plastik tentunya juga akan mempengaruhi tingkat kesuburan tanah. Efeknya, tanaman tidak dapat tumbuh secara optimal karena kekurangan unsur hara tanah. Sampah plastik merupakan polutan tanah yang dapat menimbulkan dampak yang serius.

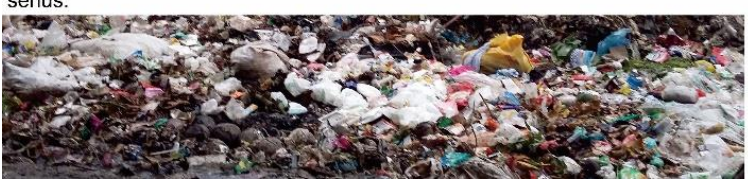

\subsection{Pengetahuan Tentang Seni Rupa dan} Kerajinan

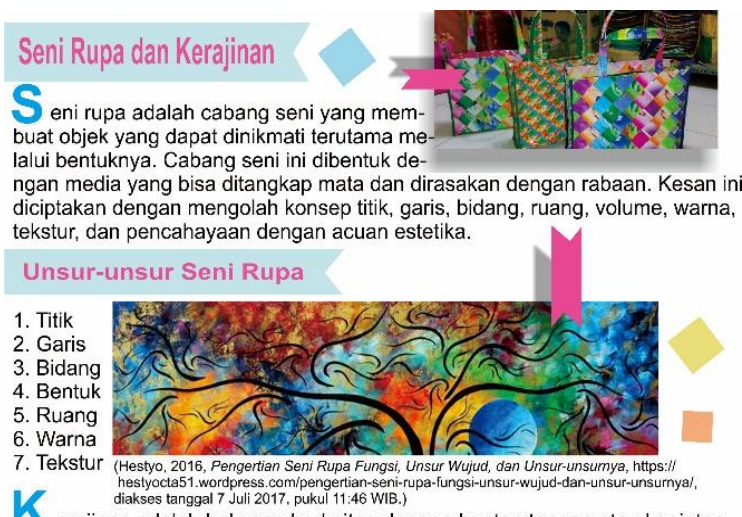

N erajinan adalah hal yang berkaitan dengan buatan tangan atau kegiatan yang berkaitan dengan barang yang dihasilkan melalui keterampilan tangan (kerajinan tangan). Kerajinan yang dibuat biasanya dari berbagai aneka jenis bahan, seperti plastik, kertas, kayu, dan lain-lain. Hasil dari kerajinan bisa berupa hiasan atau benda seni maupun barang pakai.

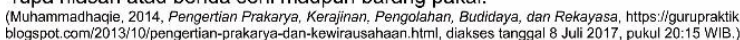

3.3 Pengetahuan Tentang Alat, Bahan yang Digunkan, dan Langkah Kerja Pembuatan Tas

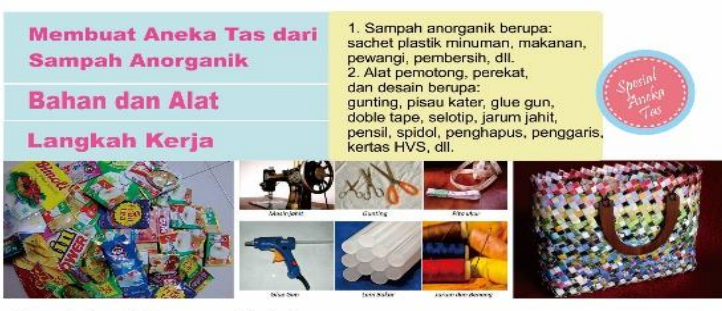

- Desain bentuk tas sesuai keinginan
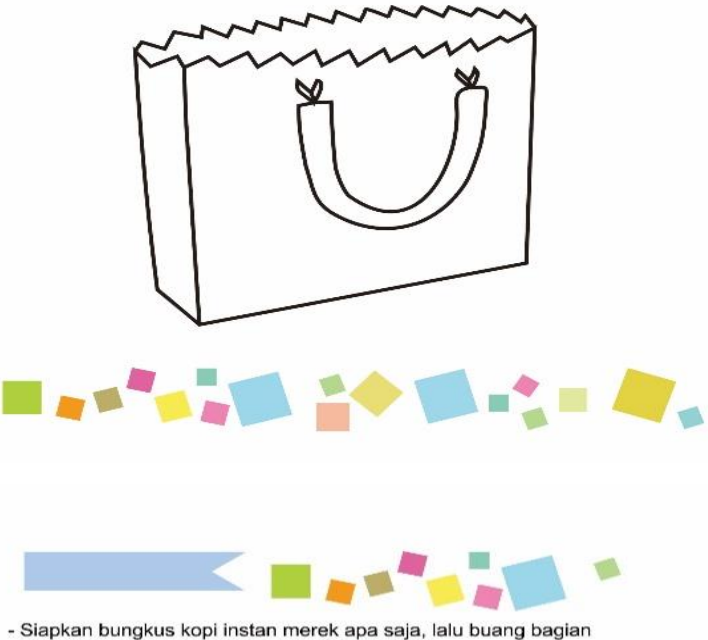

- Siapkan bungkus kopi instan merek apa saja,
atas dan bawah sehingga kedua sisi terbuaka

(bisa menggunakan bungkus pewangi, minuman, dII).

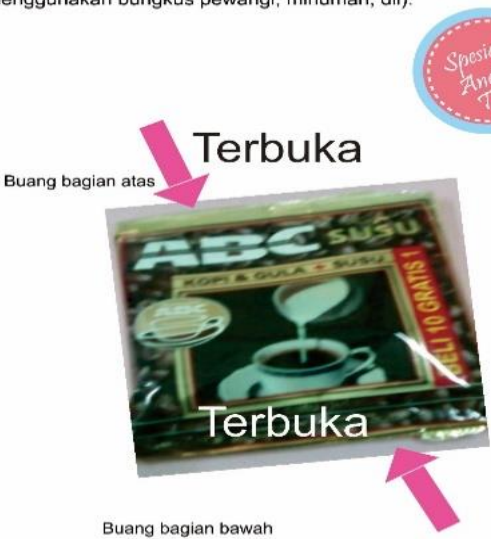

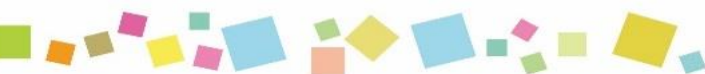




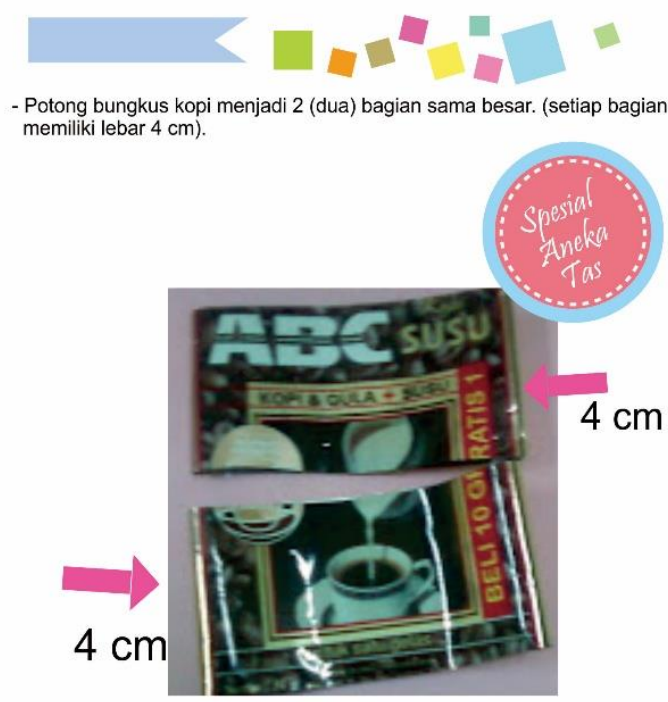

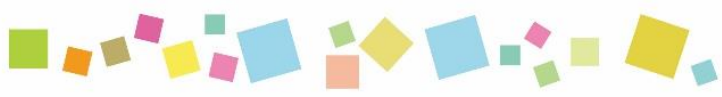

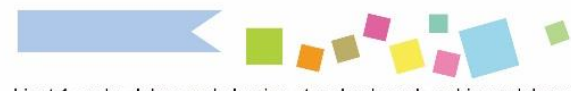

- Lipat $1 \mathrm{~cm}$ ke dalam pada bagian atas dan bawah, sehingga lebarnya menjadi $2 \mathrm{~cm}$. Buat 1000 lipatan dari 500 bungkus kopi atau

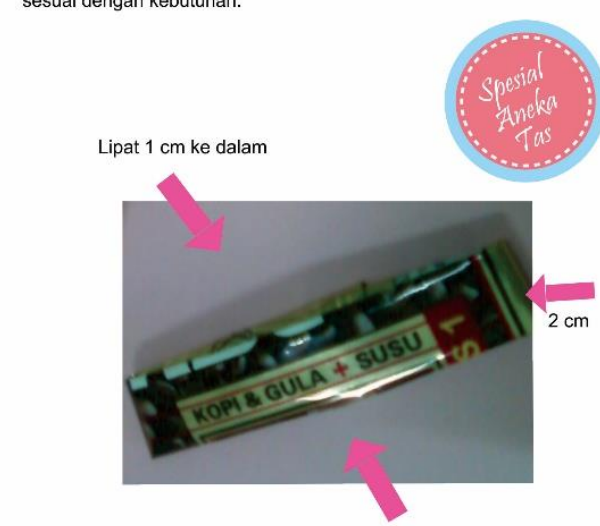

Lipat $1 \mathrm{~cm}$ ke dalam

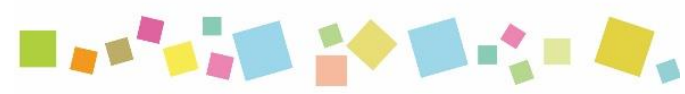

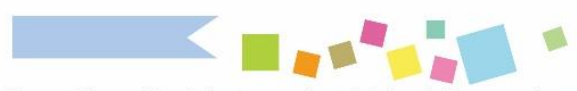

- Anyam 4 (empat) buah lipatan membentuk baling-baling, seperti gambar di bawah ini.
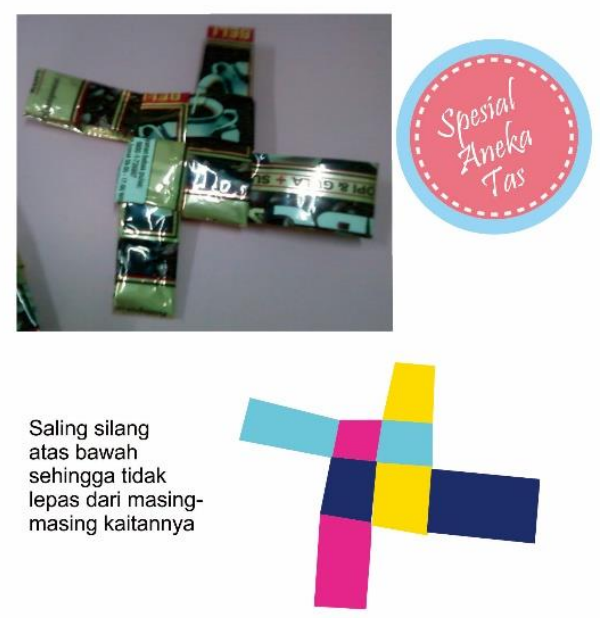

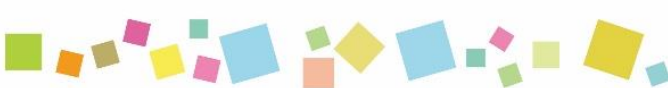
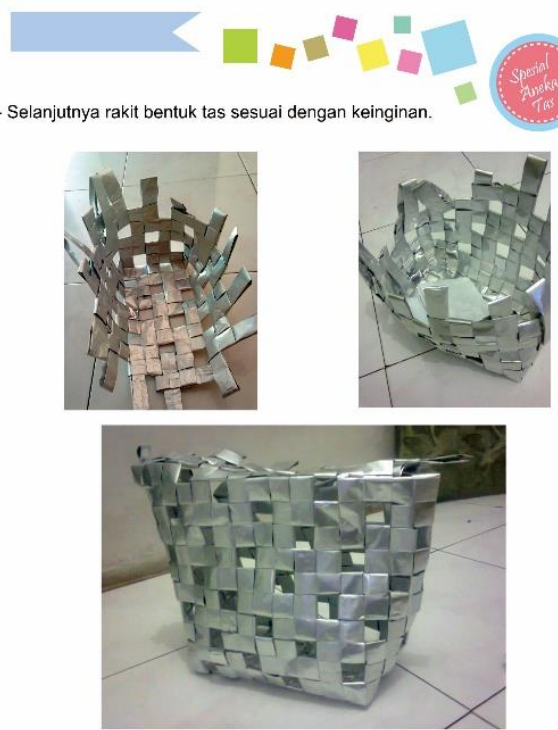

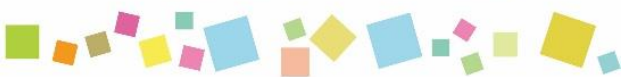

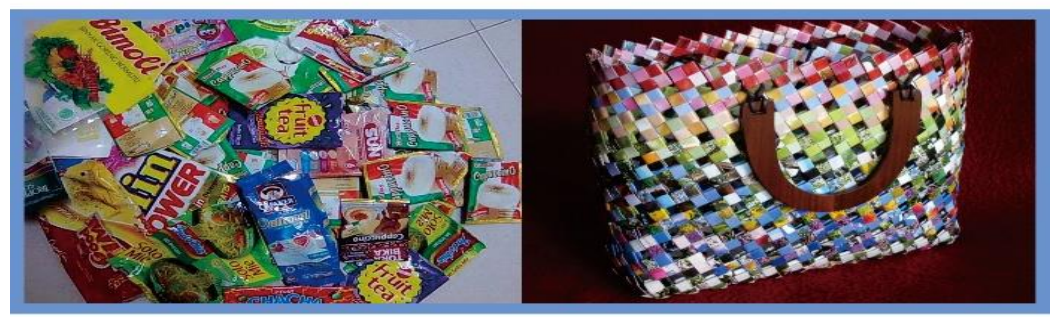


3.4Xbanner Tutorial Langkah Kerja Pembuatan Tas dari Bahan Sampah Anorganik

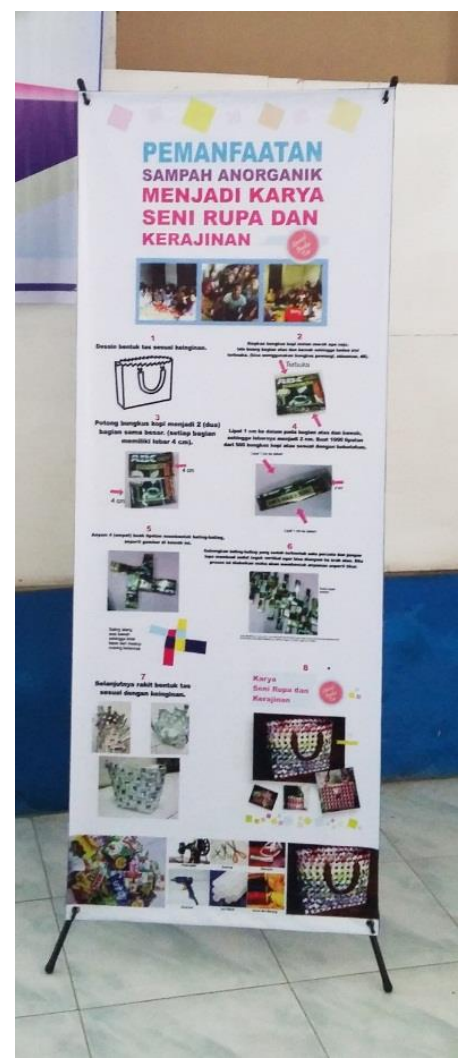

\subsection{Buku Besar Merancang Kegiatan di 2018}

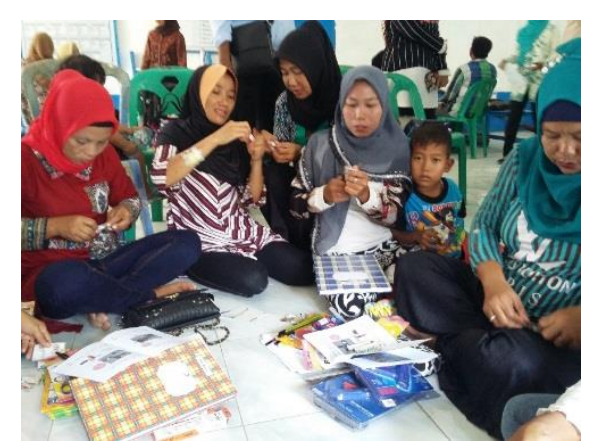

3.6 Handbook Tutorial Langkah Kerja Membuat Aneka Tas

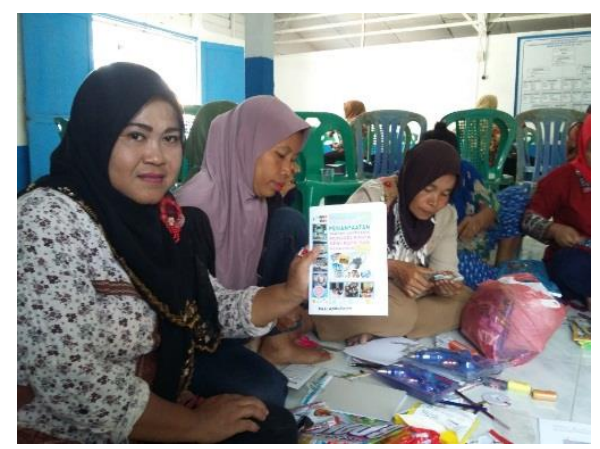

\subsection{Aneka Tas Hasil Karya Kelompok PKH Mitra}

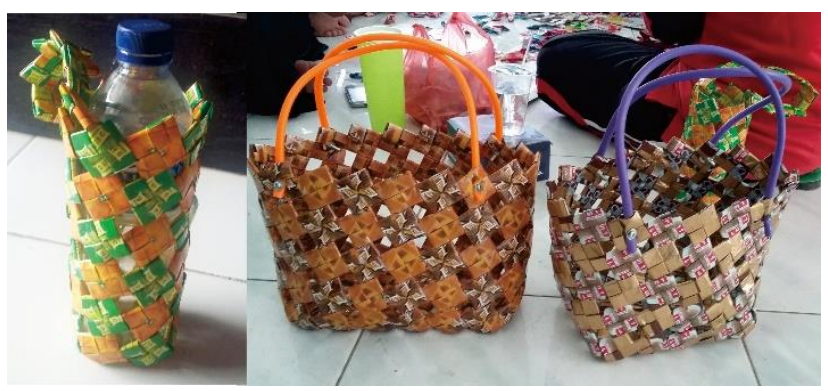

\section{KESIMPULAN}

Kegiatan Pengabdian kepada Masyarakat yang bertujuan untuk Mengoptimalisasikan Daya Kreativitas Menuju Wirausaha Madani pada Kelompok Program Keluarga Harapan (PKH) di kecamatan Deli Tua ini telah berjalan sesuai dengan rencana yang diharapkan. Kelompok PKH Mitra dalam kegiatan ini yakni Andaliman, Kenanga, dan Mawar. Kelompok PKH Andaliman, Kenanga, dan Mawar adalah kelompok Ibu-ibu rumah tangga penggerak pembuatan karya kerajinan. Dengan adanya kegiatan ini, kelompok Ibu-ibu ini merasakan manfaat yang signifikan, salah satunya mereka bisa memanfaatkan sampah sebagai bahan baku pembuatan kerajinan. Mendapatkan kemudahan dalam mengolah bahan dengan adanya alat tepat guna yang telah diberikan oleh tim dan pengetahuan baru tentang seni rupa dan kerajinan.

\section{DAFTAR PUSTAKA}

Hestyo, 2016, Pengertian Seni Rupa Fungsi, Unsur Wujud, dan Unsur-unsurnya, https://hestyocta51,

wordpress.com/pengertian-seni-rupa-fungsiunsur-wujud-dan-unsur-unsurnya/, diakses tanggal 7 Juli 2017, pukul 11:46 WIB

Muhammadhaqie, 2014, Pengertian Prakarya, Kerajinan, Pengolahan, Budidaya, dan Rekayasa, https://gurupraktik. Blogspot.com/2013/10/pengertian-prakaryadan kewirausahaan.html, diakses tanggal 8 Juli 2017, pukul 20:15 WIB

Rizalardiansyah, 2014, Alasan dan Dampak Membuang Sampah, https://rizalardiansyah25.blogspot.co.id/2014/ 02/alasan-dan-dampak-membuang-sampah-di. Html, diakses tanggal 7 Juli 2017, pukul 11:35 WIB

Wikipedia, 2017, Sampah Anorganik, https//id.m.wikipediasampahanorganik.org/2017/04, diakses tanggal 7 Juli 2017, pukul 11:30 WIB

www.wikipedia.org bahaya sampah plastik (16/05/2017/02:42am) 